ISSN 2089-8703 (Print) Vol. 6, No. 2 (2017)

ISSN 2442-5419 (Online)

\title{
ANALISIS HABITS OF MIND MATEMATIS SISWA SMP DI KOTA TANGERANG
}

\author{
Prahesti Tirta Safitri \\ Universitas Muhammadiyah Tangerang \\ prahestitirta@gmail.com
}

\begin{abstract}
This research is motivated by the ability of Habits of mind that is very supportive of the learner's appearance in everyday life. Habits of mind are the root of the students' strength in exercising their ability to determine solutions in problems. Purpose in this research is to know (1) How mathematical habits of mind student of junior high school in Tangerang City? and (2) Based on 16 indicators of mathematical habits of mind studied on which indicator the highest and lowest scores? This research is a qualitative descriptive study. The subject of this research is 78 students of IX class SMP spread in Tangerang City in odd semester of academic year 2016/2017. Technique of taking the subject of this research is "simple random sampling". Based on research results HOM obtained there are 16 statements given, the indicator that got the highest average is on the 16th indicator that is "the student is willing to keep learning" with the percentage of student's answer is 83,01\% and that got the lowest mean is at indicator to 6 that is "student able to check the accuracy" that is of $64.10 \%$.
\end{abstract}

Keywords: Mathematical Habits of Mind, Mathematics at Secondary Education

\section{PENDAHULUAN}

Pada perkembangannya, saat ini manusia membutuhkan kecakapan dalam menjalankan kehidupannya. Kecapakankecakapan hidup yang baik yang ada pada manusia tersebut akan membuat individu tersebut bertahan dari persaingan global. Berdasarkan hasil diskusi dengan beberapa guru di sekolah dapat disimpulkan bahwa saat ini ada sebagian anak yang tidak siap menghadapi evaluasi yang diberikan oleh guru sehingga yang terjadi adalah mereka berpikiran negatif untuk melakukan kecurangan saat evaluasi diberikan. Hal tersebut dimulai dengan pikiran mereka yang telah kehilangan kekuatan kebaikan. Mereka tidak membiasakan untuk selalu berpikiran positif sehingga kecurangan tersebut terjadi. hal tersebut perlu ditinjau lebih dalam lagi melalui kebiasaan pikiran.

Dengan begitu penting untuk disadari bahwa kebutuhan mereka akan pola berpikir positif harus dikembangkan sejak dini. Pola berpikir tersebut mereka dapatkan melalui kebiasaan pikiran atau yang disebut Habits of Mind. Manusia dengan habits of mind yang baik akan berakibat pada proses berkehidupan manusia tersebut. Karenanya setiap individu membutuhkan kebiasaan pikiran agar menghasilkan perlakuan yang baik. 
McGregor menyatakan bahwa
sebagai pendidik, penting untuk menjabarkan jarak pada kemampuan berpikir siswa yang sangat masuk akal untuk dipelihara, untuk merealisasikan seberapa pentingnya mereka, kemudian untuk merencanakan bagaimana mereka terdorong secara ekstrinsik di sekolah (2007). Kebiasaan pikiran mereka menjadi tolak ukur bagi mereka untuk berkehidupan lebih baik di masa mendatang. Salah satu prosesnya tentu didapat dari lingkungan sekolah karena mereka menghabiskan banyak waktu disana. Safitri (2013) menambahkan bahwa guru benar-benar harus bisa melihat kebiasaan berpikir siswa tersebut ketika terjadi proses pembelajaran dan guru memiliki peranan penting minimal untuk mengingatkan siswa akan pentingnya kebiasaan berpikir, sehingga mereka terbantu dalam menyelesaikan berbagai tugas.

Perubahan perilaku yang ada pada manusia akan menentukan proses arah hidupnya. Perilaku yang buruk berasal dari kebiasaan berpikir yang negatif, haruslah dirubah dengan kebiasaan pikiran yang positif agar menghasilkan perilaku yang baik sehingga tercipta proses berkehidupan yang lebih baik dari sebelumnya. Perilaku manusia dimulai dari kebiasaan hidup sejak dini. Anak yang dibiasakan dengan pola berpikir yang positif akan mencapai titik maksimal jika proses pengawasan pikiran berlangsung dengan baik. Berpikir positif juga harus didukung oleh komponen yang tepat. Hal tersebut disampaikan oleh pernyataan Ubaedy (2007) bahwa berpikir positif merupakan suatu kesatuan yang terdiri dari tiga komponen, yaitu muatan pikiran, penggunaan pikiran, dan pengawasan pikiran. Maka dari itu kebiasaan pengawasan pikiran akan memandu masa depan anak tersebut kedepannya menjadi lebih baik lagi.

Pengembangan kebiasaan pikiran dapat dimulai sejak sejak mereka berasa di bangku sekolah. Costa dan Kallick (2012) menyatakan bahwa kebiasaankebiasaan pikiran dapat menjadi komponen yang integral dalam setiap mata pelajaran sekolah, dan mereka dapat menentukan pencapaian tujuan apapun, saat seseorang keluar menuju kehidupan nyata. Saat ini peserta didik perlu untuk meningkatkan proses kegiatan yang mengarah kepada kebiasaan pikiran. Hal tersebut dikarenakan berpikir akan menjadi kebiasaan yang mempengaruhi perilaku berkehidupan seseorang. Baik atau tidaknya cara berkehidupan tiap individu dipengaruhi oleh kebiasaan pikiran yang mereka miliki. Costa dan Kallick (2012) juga menambahkan bahwa kebiasaan pikiran memberikan seperangkat perilaku yang mendisiplinkan proses intelektual. Dengan demikian intelektualitas seseorang dapat berkembang dengan baik, jika diiringi dengan kebiasaan pikiran yang positif. Lebih spesifik lagi kebiasaan pikiran (habits of mind) akan sangat mempengaruhi kemampuan siswa dalam mempelajari suatu materi dalam pembelajaran matematika.

Nurmaulita (2012) menyampaikan bahwa Habits of mind dapat juga dikatakan sebagai suatu perilaku positif yang ditunjukkan oleh siswa yang dilakukan secara berulang-ulang dari waktu ke waktu secara otomatis. Habits of mind bukan merupakan bakat alamiah atau faktor bawaan melainkan suatu kebiasaan perilaku yang dipelajari dengan secara sengaja dan sadar selama beberapa waktu. Habits of mind dapat juga digunakan sebagai respon terhadap 
pertanyaan dan jawaban sebuah masalah yang tidak segera diketahui sehingga guru dapat mengamati bagaimana siswa menghasilkan sebuah pengetahuan dari pada hanya mengingat pengetahuan tersebut.

Berdasarkan hasil diksusi dengan guru matematika di beberapa Sekolah Menengah Pertama, didapatkan beberapa poin yang terkait, diantaranya: melalui proses pengamatan guru, beberapa siswa seringkali tidak fokus dalam mengerjakan soal yang diberikan akibatnya mereka melakukan kesalahan saat mengerjakannya, kemudian siswa kadangkala tidak yakin terhadap jawabannya, hal ini dilihat dari siswa mencoret hasil dari pengerjaan sebelumnya dan diganti dengan jawaban yang baru, padahal setelah diperiksa oleh guru jawaban siswa yang pertama kadangkala benar. Dua hal diatas adalah hal yang menjadi temuan di sekolah. Dengan demikian perlu adanya pengetahuan bagaimana kebiasaan pikiran siswa di sekolah.

Costa dan Kallick (2012)

menjelaskan bahwa terdapat 16 karakteristik kebiasaan pikiran yaitu: (1) berteguh hati; (2) mengendalikan impulsivitas; (3) mendengarkan dengan pengertian dan empati; (4) berpikir fleksibel; (5) berpikir tentang berpikir (metakognitif); (6) memeriksa akurasi; (7) mempertanyakan dan menemukan permasalahan; (8) menerapkan pengetahuan masa lalu di situasi baru; (9) berpikir dan berkomunikasi dengan jelas dan cermat; (10) mencari data dengan semua indra; (11) berkarya, berimajinasi, berinovasi; (12) menanggapi dengan kekaguman dan keheranan; (13) mengambil resiko yang bertanggung jawab; (14) melihat humor; (15) berpikir secara interdependen; dan (16) bersedia terus belajar.

Kesemua karakteristik yang telah disebutkan di atas merupakan indikator yang menjadi dasar dari penelitian ini. Dengan demikian untuk mengoptimalkan habits of mind matematis siswa, maka diperlukan upaya awal untuk mengkaji habits of mind matematis siswa berdasarkan tiga kategori (tinggi, sedang, dan rendah). Adapun tujuan dalam penelitian ini adalah untuk mengetahui (1) Bagaimana habits of mind matematis siswa SMP di Kota Tangerang? Dan (2) Dari ke-16 indikator habits of mind matematis yang diteliti pada indikator mana skor tertinggi dan terendahnya?

\section{METODE PENELITIAN}

Penelitian ini merupakan penelitian deskriptif kualitatif. Subjek penelitian ini adalah 78 siswa kelas IX SMP yang tersebar di Kota Tangerang pada semester ganjil tahun ajaran 2016/2017. Teknik pengambilan subjek penelitian ini adalah "simple random sampling". Adapun instrumen yang digunakan dalam penelitian ini adalah angket Habits of Mind yang memuat pernyataan-pernyataan yang berisikan 16 indikator. Instrumen yang sudah dibuat diujikan dahulu kepada para ahli kemudian diberikan kepada subjek penelitian yang kemudian di analisis lebih lanjut. Pengolahan data kualitatif dalam penelitian ini dilakukan dengan menggunakan Microsoft Office Excel 2010 untuk menghitung presentasi skor habits of mind secara keseluruhan dan ditinjau berdasarkan masing-masing indikator. 
ISSN 2089-8703 (Print) Vol. 6, No. 2 (2017)

ISSN 2442-5419 (Online)

\section{HASIL PENELITIAN DAN PEMBAHASAN}

\section{Analisis Angket Habits of Mind Dilihat dari Distribusi Jawaban Siswa}

Data habits of mind (HOM) diperoleh melalui penyebaran skala HOM kepada siswa SMP di Kota Tangerang.
Skor habits of mind siswa didapat dengan cara mempositifkan seluruh pernyataan dan skor ini dirubah dari data ordinal ke dalam data interval. Berdasarkan data HOM Matematis siswa, diperoleh $\bar{x}=48,15$ dan $\mathrm{SD}=4,48$ sehingga kriteria pengelompokkan siswa adalah sebagai berikut:

Tabel 1. Kriteria Pengelompokan Siswa Berdasarkan Skor Hom

\begin{tabular}{|c|c|}
\hline Kelompok & Ketentuan \\
\hline Atas & Skor HOM $\geq 52,64$ \\
\hline Tengah & $\leq 43,66$ Skor HOM $<52,64$ \\
\hline Bawah & Skor HOM $<43,66$ \\
\hline
\end{tabular}

Berikut ini adalah jumlah siswa pada tiap kelompok.

Tabel 2. Data Banyaknya Siswa Berdasarkan Skor Hom

\begin{tabular}{|c|c|}
\hline Kelompok & Banyaknya Siswa \\
\hline Tinggi & 13 \\
\hline Sedang & 56 \\
\hline Rendah & 9 \\
\hline Total & 78 \\
\hline
\end{tabular}

Berdasarkan Tabel 2 di atas diketahui pada kelompok tinggi berjumlah 13 orang, kelompok sedang berjumlah 56 orang dan kelompok rendah berjumlah 9 orang. Dengan demikian dapat terlihat masih ada siswa yang memiliki habits of mind pada kategori rendah. Untuk lebih jelas lagi akan dideskripsikan kecenderungan distribusi jawaban siswa SMP di Kota Tangerang berdasarkan aspek habits of mindmana yang lebih dominan. Distribusi skor skala habits of mind disajikan secara keseluruhan pada Tabel 3 sebagai berikut.

Tabel 3. Distribusi Skor Skala Habits of Mind

\begin{tabular}{|c|c|c|c|c|c|c|}
\hline \multirow{2}{*}{ No } & Indikator & \multirow{2}{*}{ Keterangan } & \multicolumn{4}{|c|}{ Jawaban } \\
\cline { 3 - 7 } & & & SS & S & TS & STS \\
\hline \multirow{2}{*}{1} & Berteguh hati & Frekuensi & 13 & 54 & 11 & - \\
\cline { 3 - 7 } & & Presentasi & $16,67 \%$ & $69,23 \%$ & $14,1 \%$ & - \\
\hline \multirow{2}{*}{2} & Mengendalikan impulsivitas & Frekuensi & 24 & 52 & 2 & - \\
\cline { 3 - 7 } & & Presentasi & $30,76 \%$ & $66,67 \%$ & $2,57 \%$ & - \\
\hline \multirow{2}{*}{3} & \multirow{2}{*}{$\begin{array}{c}\text { Mendengarkan dengan } \\
\text { pengertian dan empati }\end{array}$} & Frekuensi & 20 & 55 & 3 & - \\
\cline { 3 - 7 } & Berpikir fleksibel & Presentasi & $25,64 \%$ & $70,51 \%$ & $3,85 \%$ & - \\
\hline 4 & & Frekuensi & 11 & 58 & 9 & - \\
\cline { 3 - 7 } & & Presentasi & $14,10 \%$ & $74,35 \%$ & $11,55 \%$ & - \\
\hline
\end{tabular}

208 | Aksioma

Jurnal Pendidikan Matematika FKIP Univ. Muhammadiyah Metro 
ISSN 2089-8703 (Print) Vol. 6, No. 2 (2017)

ISSN 2442-5419 (Online)

\begin{tabular}{|c|c|c|c|c|c|c|}
\hline \multirow[t]{2}{*}{5} & \multirow{2}{*}{$\begin{array}{l}\text { Berpikir tentang berpikir } \\
\text { (Metakognisi) }\end{array}$} & Frekuensi & 4 & 17 & 48 & 9 \\
\hline & & Presentasi & $5,12 \%$ & $21,79 \%$ & $61,53 \%$ & $11,56 \%$ \\
\hline \multirow[t]{2}{*}{6} & \multirow[t]{2}{*}{ Memeriksa Akurasi } & Frekuensi & 5 & 30 & 35 & 8 \\
\hline & & Presentasi & $6,41 \%$ & $38,46 \%$ & $44,87 \%$ & $10,26 \%$ \\
\hline \multirow[t]{2}{*}{7} & \multirow{2}{*}{$\begin{array}{c}\text { Mempertanyakan dan } \\
\text { menemukan permasalahan }\end{array}$} & Frekuensi & 29 & 44 & 5 & - \\
\hline & & Presentasi & $37,17 \%$ & $56,41 \%$ & $6,42 \%$ & - \\
\hline \multirow[t]{2}{*}{8} & \multirow{2}{*}{$\begin{array}{c}\text { Menerapkan pengetahuan } \\
\text { masa lalu di situasi baru }\end{array}$} & Frekuensi & 9 & 47 & 22 & - \\
\hline & & Presentasi & $11,53 \%$ & $60,25 \%$ & $28,22 \%$ & - \\
\hline \multirow[t]{2}{*}{9} & \multirow{2}{*}{$\begin{array}{c}\text { Berpikir dan berkomunikasi } \\
\text { dengan jelas dan cermat }\end{array}$} & Frekuensi & 8 & 55 & 15 & - \\
\hline & & Presentasi & $10,25 \%$ & $70,51 \%$ & $19,24 \%$ & - \\
\hline \multirow[t]{2}{*}{10} & \multirow{2}{*}{$\begin{array}{l}\text { Mengumpulkan data dengan } \\
\text { semua indra }\end{array}$} & Frekuensi & 9 & 43 & 24 & 2 \\
\hline & & Presentasi & $11,53 \%$ & $55,12 \%$ & $30,76 \%$ & $2,59 \%$ \\
\hline \multirow[t]{2}{*}{11} & \multirow{2}{*}{$\begin{array}{c}\text { Berkarya, berimajinasi, } \\
\text { berinovasi }\end{array}$} & Frekuensi & - & 7 & 56 & 15 \\
\hline & & Presentasi & - & $8,97 \%$ & $71,79 \%$ & $19,24 \%$ \\
\hline \multirow[t]{2}{*}{12} & \multirow{2}{*}{$\begin{array}{c}\text { Menanggapi dengan } \\
\text { kekaguman dan keheranan }\end{array}$} & Frekuensi & 17 & 55 & 6 & - \\
\hline & & Presentasi & $21,79 \%$ & $70,51 \%$ & $7,7 \%$ & - \\
\hline \multirow[t]{2}{*}{13} & \multirow{2}{*}{$\begin{array}{c}\text { Mengambil resiko yang } \\
\text { bertanggung jawab }\end{array}$} & Frekuensi & 2 & 28 & 42 & 6 \\
\hline & & Presentasi & $2,56 \%$ & $35,89 \%$ & $53,84 \%$ & $7,71 \%$ \\
\hline \multirow[t]{2}{*}{14} & \multirow[t]{2}{*}{ Melihat Humor } & Frekuensi & 20 & 50 & 8 & - \\
\hline & & Presentasi & $25,64 \%$ & $64,10 \%$ & $10,26 \%$ & - \\
\hline \multirow[t]{2}{*}{15} & \multirow[t]{2}{*}{ Berpikir secara interdependen } & Frekuensi & - & 9 & 55 & 14 \\
\hline & & Presentasi & - & $11,53 \%$ & $70,51 \%$ & $17,96 \%$ \\
\hline \multirow[t]{2}{*}{16} & \multirow[t]{2}{*}{ Bersedia terus belajar } & Frekuensi & 1 & 6 & 36 & 35 \\
\hline & & Presentasi & $1,28 \%$ & $7,69 \%$ & $46,15 \%$ & $44,88 \%$ \\
\hline \multirow{2}{*}{\multicolumn{2}{|c|}{ Skor Total }} & Frekuensi & 172 & 610 & 377 & 89 \\
\hline & & Presentasi & $13,78 \%$ & $48,87 \%$ & $30,20 \%$ & $7,15 \%$ \\
\hline
\end{tabular}

Distribusi skor skala habits of mind pada Tabel 1 diatas akan dijelaskan secara lengkap sebagai berikut. Secara rinci akan dideskripsikan hasil angket perindikator pada Tabel berikut.
1. Siswa mampu berteguh hati. Distribusi skor skala habits of mind untuk indikator tersebut dapat dilihat pada table 4 berikut.

Tabel 4. Distribusi Skala Habits of Mind pada Indikator "Siswa Mampu Berteguh Hati"

\begin{tabular}{|l|c|c|c|c|}
\hline \multirow{2}{*}{ Pernyataan } & \multicolumn{4}{|c|}{ Jawaban } \\
\cline { 2 - 5 } & SS & S & TS & STS \\
\hline $\begin{array}{l}\text { Saya mencoba berkali-kali ketika gagal } \\
\text { menyelesaikan soal matematika }\end{array}$ & 13 & 54 & 11 & - \\
\cline { 2 - 5 } & $16,67 \%$ & $69,23 \%$ & $14,1 \%$ & - \\
\hline
\end{tabular}

Pada aspek berteguh hati, sebanyak $16,67 \%$ siswa menjawab sangat setuju dan $69,23 \%$ siswa menjawab setuju. Pada pernyataan ini mereka merasa tertantang ketika kesulitan dalam proses menyelesaikan soal matematika. Hal ini nampak pada kecenderungan 
ISSN 2089-8703 (Print) Vol. 6, No. 2 (2017)

ISSN 2442-5419 (Online)

jawaban siswa menjawab setuju pada indikator siswa berteguh hati dalam suatu situasi ini. Namun sayangnya masih saja ada siswa yang menjawab tidak setuju sebesar $14,1 \%$. Walaupun angka tersebut tidak besar, hanya 11 siswa dari 78 siswa namun hal ini perlu untuk diperhatikan oleh para guru, khususnya guru matematika agar dalam proses pembelajaran selanjutnya guru tetap memberikan motivasi agar siswa tidak mudah menyerah dalam menyelesaikan soal matematika.

2. Siswa mampu mengendalikan impulsivitas. Distribusi skor skala habits of mind untuk indikator tersebut dapat dilihat pada Tabel 5 berikut.

Tabel 5. Distribusi Skala Habits of Mind pada Indikator "Siswa Mampu Mengendalikan Impulsivitas"

\begin{tabular}{|c|c|c|c|c|}
\hline Pernyataan & \multicolumn{4}{|c|}{ Jawaban } \\
\cline { 2 - 5 } & SS & S & TS & STS \\
\hline $\begin{array}{c}\text { Saya berusaha memahami perintah yang ada } \\
\text { dalam soal sebelum menyelesaikan masalah } \\
\text { matematika yang diberikan }\end{array}$ & 24 & 52 & 2 & - \\
\cline { 3 - 5 } \begin{tabular}{c} 
matem \\
\cline { 2 - 5 }
\end{tabular} & $30,76 \%$ & $66,67 \%$ & $2,57 \%$ & - \\
\hline
\end{tabular}

Pada aspek mengendalikan impulsivitas, sebanyak 30,76\% siswa menjawab sangat setuju, 66,67\% siswa menjawab setuju, dan $2,57 \%$ siswa menjawab tidak setuju. Distribusi kecenderungan jawaban siswa dapat dilihat pada pernyataan ini. Hal ini nampak pada kecenderungan jawaban siswa menjawab setuju pada indikator siswa mampu mengendalikan impulsivitas. Namun dari hasil distribusi jawaban siswa juga terlihat $2,57 \%$ siswa tidak berusaha memahami perintah dengan baik, sehingga pada proses pembelajaran mereka akan mengalami kesulitan dalam menyelesaikan masalah yang diberikan. Siswa bertanya kepada guru seumpama mereka merasa kesulitan memahami perintah dalam kartu soal yang diberikan, dengan begitu dapat disimpulkan bahwa kebiasaan siswa pada indikator habits of mind yang kedua ini,siswa berusaha memahami perintah sebelum menyelesaikan masalah matematika yang diberikan.

3. Siswa mendengarkan dengan perhatian dan empati.Distribusi skor skala habits of mind untuk indikator tersebut dapat dilihat pada Tabel 6 . berikut.

Tabel 6. Distribusi Skala Habits of Mind pada Indikator "Siswa Mendengarkan dengan Pengertian dan Empati"

\begin{tabular}{|c|c|c|c|c|}
\hline \multirow{2}{*}{ Pernyataan } & \multicolumn{4}{|c|}{ Jawaban } \\
\cline { 2 - 5 } & SS & S & TS & STS \\
\hline Saya berkonsentrasi ketika menyimak & 20 & 55 & 3 & - \\
\cline { 2 - 5 } $\begin{array}{c}\text { penjelasan dari teman dalam proses } \\
\text { pembelajaran matematika }\end{array}$ & $25,64 \%$ & $70,51 \%$ & $3,85 \%$ & - \\
\hline
\end{tabular}

$210 \mid$ Aksioma Jurnal Pendidikan Matematika FKIP Univ. Muhammadiyah Metro 
ISSN 2089-8703 (Print) Vol. 6, No. 2 (2017)

ISSN 2442-5419 (Online)

Pada aspek mendengarkan dengan perhatian dan empati, sebanyak $25,64 \%$ siswa menjawab sangat setuju, $70,51 \%$ siswa menjawab setuju dan $3,85 \%$ menjawab tidak setuju.Hanya sedikit sekali siswa yang menjawab tidak setuju, dengan demikian dalm diri mereka, siswa masih memiliki rasa kepekaan terhadap sesama, rasa empati kepada temannya, juga mau menjadi pendengar yang baik dalam proses pembelajaran matematika. Dengan begitu dapat disimpulkan bahwa kebiasaan siswa pada indikator habits of mind yang ketiga, siswa berkonsentrasi ketika menyimakpenjelasan dari teman dalam proses pembelajaran matematika.

4. Siswa mampu berpikir fleksibel. Distribusi skor skala habits of mind untuk indikator tersebut dapat dilihat pada Tabel 7 berikut.

Tabel 7. Distribusi Skala Habits of Mind pada Indikator "Siswa Mampu Berpikir Fleksibel"

\begin{tabular}{|c|c|c|c|c|}
\hline \multirow{2}{*}{ Pernyataan } & \multicolumn{3}{|c|}{ Jawaban } \\
\cline { 2 - 5 } & $\mathrm{SS}$ & $\mathrm{S}$ & $\mathrm{TS}$ & STS \\
\hline Saya bersedia menyesuaikan pemikiran saya \\
$\begin{array}{c}\text { ketika ada informasi baru yang lebih tepat } \\
\text { mengenai masalah matematika }\end{array}$ & 11 & 58 & 9 & - \\
\cline { 2 - 5 } & $14,10 \%$ & $74,35 \%$ & $11,55 \%$ & - \\
\hline
\end{tabular}

Pada aspek berpikir fleksibel, sebanyak $14,10 \%$ siswa menjawab sangat setuju, 74,35\% siswa menjawab setuju, dan $11,55 \%$ menjawab tidak setuju. Distribusi kecenderungan jawaban siswa dapat dilihat pada pernyataan ini. Hal ini nampak pada kecenderungan jawaban siswa menjawab setuju pada indikator siswa mampu berpikir fleksibel. Kegiatan belajar yang bersifat kontinuitas merangsang siswa untuk harus berpikir secara berkelanjutan. Dengan begitu sudah tepat apabila siswa bersedia menyesuaikan pemikiran ketika ada informasi baru yang lebih tepat mengenai masalah matematika.

5. Siswa mampu berpikir tentang berpikir (metakognitif) dalam suatu situasi.Distribusi skor skala habits of mind untuk indikator tersebut sebagai berikut.

Tabel 8. Distribusi Skala Habits of Mind pada Indikator "Siswa Mampu Berpikir Tentang Berpikir (Metakognisi) Dalam Suatu Situasi”

\begin{tabular}{|c|c|c|c|c|}
\hline \multirow{2}{*}{ Pernyataan } & \multicolumn{4}{|c|}{ Jawaban } \\
\cline { 2 - 5 } & $\mathrm{SS}$ & $\mathrm{S}$ & $\mathrm{TS}$ & $\mathrm{STS}$ \\
\hline $\begin{array}{c}\text { Saya tidak mengevaluasi diri ketika } \\
\text { saya berbuat kesalahan dalam } \\
\text { menyelesaikan persoalan } \\
\text { matematika }\end{array}$ & 4 & 17 & 48 & 9 \\
\cline { 2 - 5 } & $5,12 \%$ & $21,79 \%$ & $61,53 \%$ & $11,56 \%$ \\
\hline
\end{tabular}

Pada aspek berpikir tentang berpikir, sebanyak $5,12 \%$ siswa menjawab sangat setuju, 21,79\% siswa menjawab setuju, $61,53 \%$ menjawab tidak setuju, dan 
ISSN 2089-8703 (Print) Vol. 6, No. 2 (2017)

ISSN 2442-5419 (Online)

$11,56 \%$ menjawab sangat tidak setuju.Distribusi jawaban siswa masih menyebar. Walaupun jawaban terbanyak ada pada jawaban tidak setuju. Namun sangat disayangkan masih ada siswa yag menjawab sangat setuju dan setuju. Padahal evaluasi diri merupakan hal yang penting dalam proses pembelajaran. Jika

siswa tidak mengevaluasi diri dalam pembelajaran maka proses mencapai keadaan yang lebih baik akan sulit diraih.

6. Siswa mampu memeriksa akurasi. Distribusi skor skala habits of mind untuk indikator tersebut dapat dilihat pada Tabel 9 berikut.

Tabel 9. Distribusi Skala Habits of Mind pada Indikator "Siswa Mampu Memeriksa Akurasi"

\begin{tabular}{|c|c|c|c|c|}
\hline Pernyataan & \multicolumn{4}{|c|}{ Jawaban } \\
\cline { 2 - 5 } & SS & S & TS & STS \\
\hline Saya tidak teliti ketika menyelesaikan & 5 & 30 & 35 & 8 \\
\cline { 2 - 5 } permasalahan matematika & $6,41 \%$ & $38,46 \%$ & $44,87 \%$ & $10,26 \%$ \\
\hline
\end{tabular}

Pada aspek memeriksa akurasi, sebanyak $6,41 \%$ siswa menjawab sangat setuju, $38,46 \%$ siswa menjawab sangat setuju, $44,87 \%$ menjawab tidak setuju, dan 10,26\% menjawab sangat tidak setuju. Pada indikator ini siswa juga masih banyak yang menjawab sangat setuju dan setuju dengan demikian masih banyak siswa yang tidak teliti ketika menyelesaikan permasalahan matematika. Padahal ketelitian merupakan tahap yang harus dilakukan oleh siswa mengingat setiap langkah saat mengerjakan soal membutuhkan ketelitian. Sayangnya masih ada siswa yang tidak teliti dan sebaiknya guru dapat memberikan perhatian khusus agar siswa dapat meningkatkan ketelitiannya. Dalam hal ini sebaiknya ada pendekatan dari guru apabila terdapat siswa yang kurang teliti saat mengerjakan soal matematika.

7. Siswa mampu mempertanyakan dan menemukan permasalahan. Distribusi skor skala habits of mind untuk indikator tersebut dapat dilihat pada Tabel 10 berikut.

Tabel 10. Distribusi Skala Habits of Mindpada Indikator "Siswa Mampu Mempertanyakan dan Menemukan Permasalahan"

\begin{tabular}{|c|c|c|c|c|}
\hline \multirow{2}{*}{ Pernyataan } & \multicolumn{4}{|c|}{ Jawaban } \\
\cline { 2 - 5 } & SS & S & TS & STS \\
\hline Saya selalu mempertanyakan tentang & 29 & 44 & 5 & - \\
\cline { 2 - 5 } $\begin{array}{c}\text { apa yang saya kurang pahami kepada } \\
\text { teman atau guru tentang persoalan } \\
\text { matematika }\end{array}$ & $37,17 \%$ & $56,41 \%$ & $6,42 \%$ & - \\
\hline
\end{tabular}

Pada aspek mempertanyakan dan menemukan permasalahan, sebanyak $37,17 \%$ siswa menjawab sangat setuju,
$56,41 \%$ menjawab setuju, dan $6,42 \%$ menjawab tidak setuju. Distribusi kecenderungan jawaban siswa tidak 
ISSN 2089-8703 (Print) Vol. 6, No. 2 (2017)

ISSN 2442-5419 (Online)

terlihat pada pernyataan ini. Hal ini nampak pada kecenderungan jawaban siswa menjawab sangat setuju dan setuju. Sesuai dengan hasil jawaban di atas terlihat siswa interaktif saat proses pembelajaran. Dengan begitu, kekurangtahuan siswa akan suatu persoalan matematika berkurang dan berdampak pada pemahaman siswa yang meningkat.

8. Siswa mampu menerapkan pengetahuan masa lalu disituasi baru. Distribusi skor skala habits of mind untuk indikator tersebut dapat dilihat pada Tabel 11 berikut.

Tabel 11. Distribusi Skala Habits of Mind pada Indikator "Siswa Mampu Menerapkan Pengetahuan Masa Lalu di Situasi Baru"

\begin{tabular}{|c|c|c|c|c|}
\hline \multirow[t]{2}{*}{ Pernyataan } & \multicolumn{4}{|c|}{ Jawaban } \\
\hline & SS & $\mathrm{S}$ & TS & STS \\
\hline Saya dapat menyiapkan dengan detail & 9 & 47 & 22 & - \\
\hline $\begin{array}{l}\text { ketika akan mempresentasikan solusi } \\
\text { permasalahan matematika }\end{array}$ & $11,53 \%$ & $60,25 \%$ & $28,22 \%$ & - \\
\hline
\end{tabular}

Pada aspek menerapkan pengetahuan masa lalu disituasi baru, sebanyak $11,53 \%$ siswa menjawab sangat setuju, 60,25\% menjawab setuju, dan $28,22 \%$ menjawab tidak setuju. Hal ini nampak pada kecenderungan jawaban siswa menjawab setuju pada indikator siswa mampu menerapkan pengetahuan masa lalu di situasi baru, namun sayangnya lebih dari $25 \%$ siswa masih belum bisa menyiapkan bahan saat mempresentasikan solusi permasalahan matematika.

9. Siswa mampu berpikir dan berkomunikasi dengan jelas dan cermat. Distribusi skor skala habits of mind untuk indikator tersebut dapat dilihat pada Tabel 12 berikut.

Tabel 12. Distribusi Skala Habits of Mind pada Indikator "Siswa Mampu Berpikir dan Berkomunikasi dengan Jelas dan Cermat"

\begin{tabular}{|c|c|c|c|c|}
\hline \multirow{2}{*}{ Pernyataan } & \multicolumn{4}{|c|}{ Jawaban } \\
\cline { 2 - 5 } & $\mathrm{SS}$ & $\mathrm{S}$ & $\mathrm{TS}$ & $\mathrm{STS}$ \\
\hline Dengan menyusun perhitungan & 8 & 55 & 15 & - \\
\cline { 2 - 5 } $\begin{array}{c}\text { yang tepat, saya bersemangat } \\
\text { untuk meyakinkan orang lain } \\
\text { bahwa solusi dari persoalan yang } \\
\text { saya kerjakan benar }\end{array}$ & $10,25 \%$ & $70,51 \%$ & $19,24 \%$ & - \\
\hline
\end{tabular}

Pada aspek berpikir dan berkomunikasi dengan jelas dan cermat, sebanyak $10,25 \%$ siswa menjawab sangat setuju, 70,51\% menjawab setuju, dan $19,24 \%$ menjawab tidak setuju. Distribusi kecenderungan jawaban siswa dapat dilihat pada pernyataan ini. Hal ini nampak pada kecenderungan jawaban siswa menjawab setuju pada indikator siswa mampu menerapkan pengetahuan masa lalu di situasi baru. Saat siswa merasa yakin akan jawabannya, sebagian besar dari mereka bersemangat meyakinkan orang lain. 
ISSN 2089-8703 (Print) Vol. 6, No. 2 (2017)

ISSN 2442-5419 (Online)

10. Siswa mampu mencari data dengan semua indra. Distribusi skor skala tersebut dapat dilihat pada Tabel 13 habits of mind untuk indikator

Tabel 13. Distribusi Skala Habits of Mind pada Indikator "Siswa Mampu Mencari Data dengan Semua Indra"

\begin{tabular}{|c|c|c|c|c|}
\hline \multirow{2}{*}{ Pernyataan } & \multicolumn{4}{|c|}{ Jawaban } \\
\cline { 2 - 5 } & SS & S & TS & STS \\
\hline $\begin{array}{c}\text { Menggunakan perasaan untuk } \\
\text { memperkirakan jawaban adalah hal } \\
\text { yang sering saya lakukan }\end{array}$ & 9 & 43 & 24 & 2 \\
\cline { 2 - 5 } & $11,53 \%$ & $55,12 \%$ & $30,76 \%$ & $2,59 \%$ \\
\hline
\end{tabular}

Pada aspek mencari data dengan semua indra, sebanyak $11,53 \%$ siswa menjawab sangat setuju, 55,12\% menjawab setuju, $30,76 \%$ menjawab tidak setuju, dan $2,59 \%$ menjawab sangat tidak setuju. Jawaban sangat setuju dan setuju lebih dari $50 \%$, namun sayang masih banyak yang memjawab tidak setuju dan sangat tidak setuju. Sebenarnya, menggunakan perasaan merupakan hal yang bisa dilakukan oleh siswa saat mereka lupa saat menyelesaikan suatu persoalan. Perasaan tersebut mengajak siswa untuk berpikir akan hal-hal yang perlu dilakukan saat menyelesaikan masalah.

11. Siswa mampu berkreasi, berimajinasi, dan berinovasi. Distribusi skor skala habits of mind untuk indikator tersebut dapat dilihat pada Tabel 14 berikut.

Tabel 14. Distribusi Skala Habits of Mind pada Indikator "Siswa Mampu Berkarya, Berimajinasi, Berinovasi"

\begin{tabular}{|c|c|c|c|c|}
\hline \multirow{2}{*}{ Pernyataan } & \multicolumn{4}{|c|}{ Jawaban } \\
\cline { 2 - 5 } & SS & S & TS & STS \\
\hline Mencari solusi baru dari masalah & - & 7 & 56 & 15 \\
\cline { 2 - 5 } matematika buang-buang waktu saja & - & $8,97 \%$ & $71,79 \%$ & $19,24 \%$ \\
\hline
\end{tabular}

Pada aspek berkreasi, berimajinasi, dan berinovasi, sebanyak $8,97 \%$ menjawab setuju, $71,79 \%$ menjawab tidak setuju, dan 19,24\% menjawab sangat tidak setuju. Distribusi kecenderungan jawaban siswa dapat dilihat pada pernyataan ini. Hal ini nampak pada kecenderungan jawaban siswa menjawab tidak setuju pada indikator siswa mampu berkreasi, berimajinasi, dan berinovasi.Dengan begitu dapat disimpulkan bahwa kebiasaan siswa pada indikator habits of mind yang kesebelas, siswa tidak merasa mencari solusi baru dari masalah matematika buang-buang waktu saja.

12. Siswa mampu menanggapi dengan kekaguman dan keheranan. Distribusi skor skala habits of mind untuk indikator tersebut dapat dilihat pada Tabel 15 berikut. 
ISSN 2089-8703 (Print) Vol. 6, No. 2 (2017)

ISSN 2442-5419 (Online)

Tabel 15. Distribusi Skala Habits of Mind pada Indikator "Siswa Mampu Menanggapi dengan Kekaguman dan Keheranan”

\begin{tabular}{|c|c|c|c|c|}
\hline \multirow{2}{*}{ Pernyataan } & \multicolumn{4}{|c|}{ Jawaban } \\
\cline { 2 - 5 } & SS & S & TS & STS \\
\hline Saya kagum ketika teman yang lain dapat \\
$\begin{array}{c}\text { menyelesaikan masalah matematika yang } \\
\text { diberikan oleh guru }\end{array}$ & 17 & 55 & 6 & - \\
\cline { 2 - 5 } & $21,79 \%$ & $70,51 \%$ & $7,7 \%$ & - \\
\hline
\end{tabular}

Pada aspek menanggapi dengan kekaguman dan keheranan, sebanyak $21,79 \%$ siswa menjawab sangat setuju, 70,51\% menjawab setuju, dan $7,7 \%$ menjawab tidak setuju. Distribusi kecenderungan jawaban siswa dapat dilihat pada pernyataan ini. Rasa kagum yang dimiliki oleh siswa membuat mereka menjadi lebih simpati kepada temannya. Hal tersebut dapat meningkatkan kemampuan tenggang rasa diantara para siswa. Hal ini nampak pada kecenderungan jawaban siswa menjawab setuju pada indikator siswa mampu menanggapi dengan kekaguman dan keheranan.

13. Siswa mengambil resiko bertanggung jawab. Distribusi skor skala habits of mind untuk indikator tersebut dapat dilihat pada Tabel 16 berikut.

Tabel 16. Distribusi Skala Habits of Mind pada Indikator "Siswa Mengambil Resiko yang Bertanggung Jawab"

\begin{tabular}{|c|c|c|c|c|}
\hline \multirow{2}{*}{ Pernyataan } & \multicolumn{4}{|c|}{ Jawaban } \\
\cline { 2 - 5 } & SS & S & TS & STS \\
\hline $\begin{array}{c}\text { Saya tidak berani mengungkapkan } \\
\text { pengetahuan yang saya miliki } \\
\text { walaupun benar }\end{array}$ & 2 & 28 & 42 & 6 \\
\cline { 2 - 5 } & $2,56 \%$ & $35,89 \%$ & $53,84 \%$ & $7,71 \%$ \\
\hline
\end{tabular}

Pada aspek mengambil resiko bertanggung jawab, sebanyak 2,56\% siswa menjawab sangat setuju, $35,89 \%$ menjawab setuju, 53,84\% menjawab tidak setuju, dan $7,71 \%$ menjawab sangat tidak setuju. Distribusi jawaban siswa dapat dilihat pada pernyataan ini. Lebih dari $50 \%$ siswa tidak setuju pada pernyataan ini namun sayangnya siswa masih belum percaya diri untuk mengungkapkan pengetahuan yang dimiliki. Dengan begitu dapat disimpulkan bahwa kebiasaan siswa pada indikator habits of mind yang ke- tiga belas, siswa masih ada yang tidak berani mengungkapkan pengetahuan yang dimiliki walaupun sesuai dengan materi pelajaran.

14. Siswa melihat humor. Distribusi skor skala habits of mind untuk indikator tersebut dapat dilihat pada Tabel 17 berikut.

Tabel 17. Distribusi Skala Habits of Mind pada Indikator "Melihat Humor"

\begin{tabular}{|c|c|c|c|c|}
\hline \multirow{2}{*}{ Pernyataan } & \multicolumn{4}{|c|}{ Jawaban } \\
\cline { 2 - 5 } & SS & S & TS & STS \\
\hline Saya merasa terhibur jika dalam & 20 & 50 & 8 & - \\
\hline
\end{tabular}


ISSN 2089-8703 (Print) Vol. 6, No. 2 (2017)

ISSN 2442-5419 (Online)

\begin{tabular}{|c|c|c|c|c|}
\hline $\begin{array}{c}\text { proses pembelajaran menemukan } \\
\text { sesuatu hal yang berbeda dari } \\
\text { biasanya }\end{array}$ & $25,64 \%$ & $64,10 \%$ & $10,26 \%$ & - \\
\hline
\end{tabular}

Pada aspek melihat humor, sebanyak $25,64 \%$ siswa menjawab sangat setuju, 64,10\% menjawab setuju, dan $10,26 \%$ menjawab tidak setuju. Distribusi kecenderungan jawaban siswa dapat dilihat pada pernyataan ini. Hal ini nampak pada kecenderungan jawaban siswa menjawab setuju pada indikator siswa melihat humor. Dengan begitu dapat disimpulkan bahwa kebiasaan siswa pada indikator habits of mind yang keempat belas, siswa merasa terhibur jika dalam proses pembelajaran menemukan sesuatu hal yang berbeda dari biasanya.

15. Siswa berpikir secara interdependen.Distribusi skor skala habits of mind untuk indikator tersebut dapat dilihat pada Tabel 18 berikut.

Tabel 18. Distribusi Skala Habits of Mind pada Indikator "Berpikir secara Interdependen"

\begin{tabular}{|c|c|c|c|c|}
\hline \multirow{2}{*}{ Pernyataan } & \multicolumn{4}{|c|}{ Jawaban } \\
\cline { 2 - 5 } & SS & S & TS & STS \\
\hline $\begin{array}{c}\text { Saya malas memberi dan menerima saran } \\
\text { dalam belajar sesama }\end{array}$ & - & 9 & 55 & 14 \\
\cline { 2 - 5 } & - & $11,53 \%$ & $70,51 \%$ & $17,96 \%$ \\
\hline
\end{tabular}

Pada aspek berpikir secara interdependen, sebanyak $11,53 \%$ menjawab setuju, 70,51\% menjawab tidak setuju, dan $17,96 \%$ menjawab sangat tidak setuju. Distribusi kecenderungan jawaban siswa dapat dilihat pada pernyataan ini. Hal ini nampak pada kecenderungan jawaban siswa menjawab sangat tidak setuju pada indikator siswa mampu berpikir secara interdependen. Sebaiknya guru dapat melihat karakteristik siswa dalam kegiatan belajar sesama. Jika siswa malas dalam memberi dan menerima saran, mereka akan mengalami kesulitan dalam kehidupan sehari-hari. Hal ini berimbas pada kehidupannya di masa yang akan datang.

16. Siswa bersedia untuk terus belajar. Distribusi skor skala habits of mind untuk indikator tersebut dapat dilihat pada Tabel 19 berikut.

Tabel 19. Distribusi Skala Habits of Mind pada Indikator "Bersedia Terus Belajar"

\begin{tabular}{|c|c|c|c|c|}
\hline \multirow{2}{*}{ Pernyataan } & \multicolumn{4}{|c|}{ Jawaban } \\
\cline { 2 - 5 } & SS & S & TS & STS \\
\hline $\begin{array}{c}\text { Saya memandang belajar } \\
\text { matematika adalah kegiatan yang } \\
\text { tidak berguna dan sia-sia }\end{array}$ & 1 & 6 & 36 & 35 \\
\cline { 2 - 5 } & $1,28 \%$ & $7,69 \%$ & $46,15 \%$ & $44,88 \%$ \\
\hline
\end{tabular}

Pada aspek bersedia untuk terus belajar, distribusi jawaban siswa lebih dari $90 \%$ yang tidak setuju dan sangat tidak setuju. Dengan begitu dapat disimpulkan bahwa siswa masih merasa belajar matematika bukan kegiatan yang sia-sia dan mereka masih bersedia terus 
ISSN 2089-8703 (Print) Vol. 6, No. 2 (2017)

ISSN 2442-5419 (Online)

belajar untuk meningkatkan kualitas hidup mereka.

Analisis lebih jauh dengan melihat rata-rata jawaban siswa per-indikator. Dari 16 pernyataan yang diberikan, indikator yang mendapat rerata tertinggi adalah pada indikator ke 16 yaitu "siswa bersedia terus belajar" dengan persentase jawaban siswa adalah 83,01\% dan yang mendapat rerata terendah adalah pada indikator ke 6 yaitu "siswa mampu memeriksa akurasi" yaitu sebesar $64,10 \%$.

\section{KESIMPULAN DAN SARAN}

Berdasarkan hasil penelitian dan pembahasan, dapat disimpulkan bahwa:

1. Berdasarkan skor habits of mind siswa dalam pembelajaran matematika banyaknya siswa yang ada pada kategori tinggi sebanyak 13 siswa, kategori sedang sebanyak 56 siswa, dan pada kategori rendah sebanyak 9 siswa.

2. Dari 16 indikator yang diberikan, skor tertinggi pada indikator siswa bersedia terus belajar dan skor terendah pada indikator siswa mampu memeriksa akurasi.

Saran yang dapat disampaikan pada penelitian ini adalah pada penelitian selanjutnya dapat dikaitkan antara habits of mind siswa dengan prestasi belajar siswa agar dapat dianalisis hubungan diantaranya.
DAFTAR PUSTAKA

Costa dan Kallick. (2012).Belajar dan Memimpin dengan 'Kebiasaan Pikiran'. Jakarta: Indeks.

McGregor, Debra. (2007). Developing thinking Developing Learning. Poland. Open University Press.

Nurmaulita (2012). Penerapan Pendidikan Karakter pada Mata Pelajaran Fisika melalui Pembelajaran Salingtemas untuk Membentuk Habits of Mind Siswa Kelas XI IPA di SMA Negeri 1 Tanah Jawa. [Online]. Tersedia:

www.scribd.com/doc/88542339/ Penerapan-Pendidikan-KarakterPada-Mata-Pelajaran-Fisika. [19 Januari 2013].

Ubaedy, An. (2007). Kedahsyatan Berpikir Positif. Depok: PT Visi Gagas Komunika.

Safitri, Prahesti Tirta (2013). Pembelajaran Quick on The Draw untuk Meningkatkan Kemampuan Penalaran Matematis dan Habits of Mind Siswa Sekolah Menengah Pertama. Tesis Magister pada SPs Universitas Pendidikan Indonesia Bandung: Tidak Diterbitkan. 